\title{
3: $187917822-187944445$
}

National Cancer Institute

\section{Source}

National Cancer Institute. 3: 187917822-187944445. NCI Thesaurus. Code C45098.

Physical location of KNG_Gene 